\begin{tabular}{|c|c|c|}
\hline \hline & $\begin{array}{c}\text { International Journal of Current Research in } \\
\text { Biosciences and Plant Biology }\end{array}$ \\
\hline EXCELLENT \\
PUBLISHERS
\end{tabular}

\title{
Study of Effectiveness of Serum Electrolytes and Inorganic Elements as Biomarkers in Acute Myocardial Infarction Patients
}

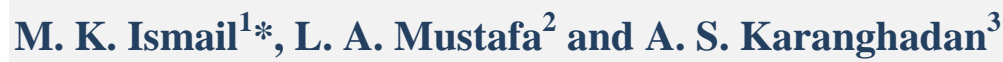 \\ ${ }^{1,3}$ Department of Biomedical Sciences, Gulf Medical University, Ajman, United Arab Emirates \\ ${ }^{2}$ Department of Chemistry, College of Science, University of Mosul, lraq
}

*Corresponding author.

\begin{abstract} followed by Se with $\mathrm{S}_{\mathrm{n}}=70 \%, \mathrm{~S}_{\mathrm{P}}=100 \%$ and $\mathrm{E}_{\mathrm{f}}=79 \%$.

\section{Introduction}

Acute myocardial infarction (AMI) is the major cause of morbidity and mortality. The incidents of death are increasing worldwide and the risk of death is very high within the first few hours of onset of the disease. A biomarker may be defined as "a characteristic that is objectively measured and evaluated as an indicator of normal biological processes or pharmacologic responses to a therapeutic intervention". The analysis and identification of various biomarkers may increase the existing diagnostic procedures for the evaluation of AMI patients (Ahmad et al., 2012).
\end{abstract}

The present study focused on the effectiveness of serum electrolytes and inorganic elements as risk and illness indicators in acute myocardial infarction (AMI) patients. Data from 317 male and female subjects with ages of 34-87 years is used in the study. The results indicated a significant decrease in serum $\mathrm{Na}^{+}, \mathrm{K}^{+}$and $\mathrm{Cl}^{-}$of AMI patients with a $p<0.001$ compared to healthy subjects. Furthermore, concentrations of $\mathrm{Mg}^{2+}$ and $\mathrm{Cu}^{2+}$ increased significantly in those patients while those of $\mathrm{Ca}^{2+}, \mathrm{Zn}^{2+}$ and Se decreased at the level of $p<0.001$. The cutoff values for the electrolytes and different inorganic elements were also estimated by calculating the sensitivity, specificity and efficiency for each of the parameters. The values of the specificity and sensitivity were used to evaluate the effectiveness of electrolytes andinorganic elements both as risk factor and markers for AMI. Among the electrolytes, $\mathrm{Na}^{+}$and $\mathrm{K}^{+}$showed the best characteristics with $\mathrm{S}_{\mathrm{n}}=100 \%$, $\mathrm{S}_{\mathrm{P}}=85 \%$ and $\mathrm{E}_{\mathrm{f}}=96 \%$ at the $95^{\text {th }}$ percentile. Among the inorganic elements, $\mathrm{Zn}^{2+}$ showed the best characteristics with $S_{n}=100 \%, S_{P}=100 \%$ and $E_{f}=100 \%$ at the $95^{\text {th }}$ percentile

\section{Article Info}

Accepted: 04 February 2017

Available Online: 06 March 2017

\section{Keywords}

Acute myocardial infarction

Cardio vascular diseases

Biomarkers

Electrolytes

Inorganic elements 
risk or illness indicators. Additionally, there are few opposed findings on the relationship between serum trace elements with lipids and lipoproteins (Al-Sabaawy, 2012). Increased incidence of electrolyte abnormalities is associated with diabetes mellitus along withdyslipidemia, hypertension, myocardial infarctionor heart failure (George et al., 2014). The present study aims at: compare the characteristics of AMI patients with healthy subjects with respect to serum electrolytes and inorganic elements, and to investigate the effectiveness of these parameters as risk or illness indicators.

\section{Materials and methods}

\section{The patients group}

The experiment was designed carefully to ensure the random selection of patient's sample that will reflect the actual state of acute myocardial infarction (AMI) among the citizens of the city of Mosul and its suburbs. Samples were collected from patients admitted to AlSalam Hospital and Ibn-Sina Hospital in Mosul. Blood samples were collected through venipuncture. The blood was immediately transferred into a polystyrene tube, incubated for 10 minutes at $37^{\circ} \mathrm{C}$ and centrifuged at $3000 \mathrm{rpm}$ for 10 minutes. The separated serum is then kept in deep freeze for the investigation (Burtis et al., 2013). A total of 161 patients were screenedwith an age

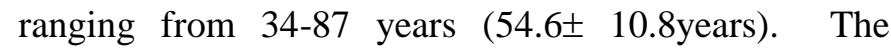
distribution is fairly normal and what is worthy to note is the relatively large number of patients in the 30-40 years age group which constituted about $12 \%$ of the total sample. Among the patients, $78.3 \%$ were males (53.9 \pm 10.9 years $)$ and $21.7 \%$ females $(57.3 \pm 10.4$ year $)$.

\section{The control group}

The control group was selected carefully from people with no history of heart diseases or others. Total of 156 individuals were sampled following the same procedure mentioned in the patients group. The mean age of the group is $45.6 \pm 11$.6years and $54.5 \%$ of the sample were male subjects.

\section{Estimation of electrolytes in serum}

$\mathrm{Na}^{+}$and $\mathrm{K}^{+}$concentration in serum were determined using flame emission spectrophotometry. The method involves a sample dilution (1:100) with de-ionized water (Bishop et al., 2010). Serum $\mathrm{Cl}^{-}$was determined by using the colorimetric method. $\mathrm{Cl}^{-}$forms soluble, nonionized complex with mercury and there by releasing thiocyanate ions which combine with ferric ions to form the colored complex "ferric thiocyanate" (Snell, 1981; Burtis et al., 2013).

\section{Estimation of inorganic elements in serum}

Serum $\mathrm{Mg}^{2+}$ was quantitatively determined by the colorimetric method which involved the reaction of Xylidyl blue with $\mathrm{Mg}^{2+}$ to form a colored complex in alkaline medium (Kaplan and Pesce, 2010). Serum $\mathrm{Ca}^{2+}$ was estimated calorimetrically by a method that involves the reaction of the $\mathrm{Ca}^{2+}$ ion in human serum with methyl thymol blue indicator (MTB) in an alkaline medium forming $\mathrm{Ca}^{2+}$-MTB complex (Burtis et al., 2013). $\mathrm{Zn}^{2+}$ and $\mathrm{Cu}^{2+}$ in serum were determined by using an atomic absorption technique which is used to estimate minute amounts of metals in biological tissues (Burtis et al., 2013). Fivefold diluted serum sample was aspirated into the atomic absorption flame. The $\mathrm{Zn}^{2+}$ and $\mathrm{Cu}^{2+}$ concentrations weremeasured by comparing the signal from diluted serum with the signal from aqueous calibrators, which were prepared in diluted glycerol matrix to stimulate the viscosity of diluted serum (D'Haese et al., 1992). Se in serum was determined by using the method which depends on the use of ophenylenediamine indicator to form a complex compound (Snell, 1981).

\section{Statistical analysis}

Results are expressed as mean \pm STD and statistical analysis was carried out using the STATISTICA 12.5 Package of Stat soft Inc (2014). For all statistical evaluations, a $p<0.05$ was considered statistically significant. A Visual Fortran program was also developed to analyze the sensitivity of different parameters. Other statistical techniques would be stated as required in due place (Snedecor and Cochran, 1986).

\section{Results and discussion}

The Table 1 shows the concentration of electrolytes in control subjects and patients with AMI and a significant decrease is seen in $\mathrm{Na}^{+}$concentration in patients with AMI as compared with healthy control subjects (14.0 \pm $0.14 \mathrm{mmol} / \mathrm{L}$ vs. $135.8 \pm 1.3 \mathrm{mmol} / \mathrm{L})$ with $(p<0.001)$. The percentage decrement is $(-89.6 \%)$. The concentration of $\mathrm{K}^{+}$in patients shows a significant decrease in comparison with that of the normal people 
$(0.15 \pm 0.007 \mathrm{mmol} / \mathrm{L}$ vs. $4.0 \pm 0.07 \mathrm{mmol} / \mathrm{L})$ with $(p<0.001)$. The percentages decrement is $(-96.2 \%)$. A significant decrease in $\mathrm{Cl}^{-}$concentration is observed $(90.8 \pm 2.8 \mathrm{mmol} / \mathrm{L})$ as compared with healthy subjects $(100.4 \pm 3.77 \mathrm{mmol} / \mathrm{L})$ with a percentage decrement of $(-9.4 \%)$. This is in agreement with the observations of Gallerani et al. (1994) and John et al. (2004).

The low level of serum $\mathrm{K}^{+}$links hypokalemia with arrhythmia and cardiac arrest in AMI are fairly strong (Abhinav et al., 2012) and hypokalemia contributes to the pathogenesis of CVD. Serum adrenaline levels are inversely correlated with serum $\mathrm{K}^{+}$in AMI, the catecholamine surge that accompanies AMI causes re distributional hypokalemia and hyperpolarizes nonischemic myocardia. Adrenaline stimulates the $\mathrm{Na}^{+}-\mathrm{K}^{+}-$ ATPase pump via beta, receptors and shifts intra cellular $\mathrm{K}^{+}$. These clinical observations suggest that these mechanisms play an important role in the pathogenesis of AMI. Patients with AMI suffering from vomiting, sweating which cause loss of electrolytes $\left(\mathrm{Na}^{+}, \mathrm{K}^{+}, \mathrm{Cl}^{-}\right)$, and also using diuretic drugs causes decrease in the level of electrolyte, these mechanism could be a possible explanation to our finding.A low $\mathrm{Na}^{+}$level $(14.0 \pm 0.14$ $\mathrm{mmol} / \mathrm{L})$ compared with control $(135.8 \pm 1.3 \mathrm{mmol} / \mathrm{L})$ (hyponatremia) may result in consuming enough $\mathrm{K}^{+}$in the diet, being over-hydrated excreting too much. Diuretics help the kidneys to excrete more water, resulting in low $\mathrm{Na}^{+}$level. The serum level of $\mathrm{Cl}^{-}$was low $(90.8 \pm 2.8 \mathrm{mmol} / \mathrm{L})$ in patient's serum when compared with control $(100.4 \pm 3.37 \mathrm{mmol} / \mathrm{L}), \mathrm{Cl}^{-}$ disorders are often a result of the same causes that disturb $\mathrm{Na}^{+}$level because $\mathrm{Cl}^{-}$passively follow $\mathrm{Na}^{+}$, hypochloremia may also occur with excessive loss of chloride from prolonged vomiting, diarrhea, aldosterone deficiency (Bishope et al., 2010).

The results in Table 2 show the concentration of some inorganic elements in control subjects and patients with AMI. It isshown that there is a significant increase (with $p<0.001)$ in serum $\mathrm{Mg}^{2+}$ concentration of AMI patients in comparison with that of the healthy group which is in disagreement with the reported observations of (Abid et al., 2002). It could be due to its concentration in cardiac tissues is 18 times that in blood (Altura et al., 1995), where its destruction as result of myocardial necrosis causes the release of $\mathrm{Mg}^{2+}$ into the systemic circulation. The administration of $\mathrm{Mg}^{2+}$ containing drugs such as antacids and laxative for patient with AMI might play a role in the elevation of serum $\mathrm{Mg}^{2+}$ level. A significant decrease in concentration of $\mathrm{Ca}^{2+}$ in patient's sera with $(p<0.001)$ is also observed and is in agreement with the observations of (Gallerani et al., 1994) and this is attributed to age related decrease in $\mathrm{Ca}^{2+}$ absorption and increase in urinary $\mathrm{Ca}^{2+}$ execration. Previous studies suggest that elevated $\mathrm{Mg}^{2+}$ levels may lead to hypocalcemia as well (Bishop et al., 2010) which confirm the present results. A significant decrease $(p<$ 0.001 ) in $\mathrm{Zn}^{2+}$ concentration is observed in AMI patients. The percentage of decrement is (93\%) which is in agreement with previously reported results (Abid et al., 2002). Such decrease may be attributed to oxidative stress which suggestsconsidering the $\mathrm{Zn}^{2+}$ as a biochemical marker of oxidative stress associated with AMI.

Compared with control group, $\mathrm{Cu}^{2+}$ concentration in the sera of patients with AMI was found to be significantly increased with $(p<0.001)$, the percentage of increment was $(22.5 \%)$, which is in agreement with (Abid et al., 2002, Bender et al., 2015). The redox activity of copper to its electronic configuration of $\mathrm{d}$ orbital which helped it to scavenge the free radical as in $\mathrm{Cu}^{2+}-\mathrm{Zn}^{2+}$-SOD. On the other hand, $\mathrm{Cu}^{2+}$ has an oxidant property by generation of free radicals in Fenton and Harber-Weiss reaction (Candeias et al., 1993). During infection or inflammatory stress, serum $\mathrm{Cu}^{2+}$ concentration rise because of the acute-phase action of Interleukin-1. $\mathrm{Cu}^{2+}$ is responsible of the events of cell damage, especially for the damage of epithelial cell coronary artery by oxidation of LDL (Jialal et al., 1998). The result also showed significant decrease in Se concentration in serum of patients with AMI with $(p<0.001)$ which is in agreement with pervious observations of (Burtis and Ashwood, 2008).

Low level of Se is one of the important factors in AMI, as it may help to protect the cell membrane against different oxygen radicals. In a stress situation with great demand for oxygen to the heart muscle, it could be that insufficient amount of the Se compound lead to the accumulation of free radicals that inflict damage to the cell membranes and triggers platelet aggregation. This aggregation is the cause for the formation of the thrombus and is one of the important risk factors for AMI (Kim, 1999). In addition, Se directly protects the endothelial cell against the accumulation of aggressive oxygen species and in the regulation of cholesterol. Finally, the clinical investigations (Shanmuga sundaram, 1999), do support the importance of Se in the cardiac function and prevention of coronary atherosclerosis. 
Table 1. Concentration of electrolytes in control subjects and patients with AMI.

\begin{tabular}{|c|c|c|c|c|}
\hline \multirow{2}{*}{ Parameter } & \multirow{2}{*}{ Sex } & \multicolumn{2}{|l|}{ Mean \pm SD } & \multirow{2}{*}{$p$-value } \\
\hline & & Control & Patients & \\
\hline \multirow[t]{3}{*}{$\mathrm{Na}^{+}(\mathrm{mmol} / \mathrm{L})$} & Male & $137.5 \pm 1.12$ & $13.9 \pm 0.15$ & $* * *$ \\
\hline & Female & $133.2 \pm 2.9$ & $14.2 \pm 0.42$ & $* * *$ \\
\hline & Total & $135.8 \pm 1.3$ & $14.0 \pm 0.14$ & $* * *$ \\
\hline \multirow[t]{3}{*}{$\mathrm{K}^{+}(\mathrm{mmol} / \mathrm{L})$} & Male & $4.2 \pm 0.08$ & $0.15 \pm 0.008$ & $* * *$ \\
\hline & Female & $3.8 \pm 0.13$ & $0.14 \pm 0.013$ & $* * *$ \\
\hline & Total & $4.0 \pm 0.07$ & $0.15 \pm 0.007$ & $* * *$ \\
\hline \multirow[t]{3}{*}{$\mathrm{Cl}^{-}(\mathrm{mmol} / \mathrm{L})$} & Male & $106.9 \pm 4.3$ & $93.3 \pm 3.4$ & $*$ \\
\hline & Female & $89.7 \pm 4.1$ & $82.5 \pm 4.5$ & $* * *$ \\
\hline & Total & $100.4 \pm 3.37$ & $90.8 \pm 2.8$ & $* * *$ \\
\hline
\end{tabular}

*** Highly Significant difference $(p<0.001)$; * Significant difference $(p<0.05)$; NS: No Significant difference $(p>0.05)$.

Table 2. Concentration of some inorganic elements in control subjects and patients with AMI.

\begin{tabular}{|c|c|c|c|c|}
\hline Parameter & Sex & Mean \pm SD & & $p$-value \\
\hline \multirow[t]{3}{*}{$\mathrm{Mg}(\mathrm{mmol} / \mathrm{L})$} & Male & $0.84 \pm 0.02$ & $0.92 \pm 0.01$ & $*$ \\
\hline & Female & $0.86 \pm 0.06$ & $0.95 \pm 0.03$ & NS \\
\hline & Total & $0.85 \pm 0.03$ & $0.92 \pm 0.01$ & $* * *$ \\
\hline \multirow[t]{3}{*}{$\mathrm{Ca}(\mathrm{mmol} / \mathrm{L})$} & Male & $2.5 \pm 0.07$ & $2.2 \pm 0.05$ & $* * *$ \\
\hline & Female & $2.4 \pm 0.06$ & $2.1 \pm 0.06$ & $* * *$ \\
\hline & Total & $2.5 \pm 0.05$ & $2.2 \pm 0.05$ & $* * *$ \\
\hline $\mathrm{Zn}(\mu \mathrm{mol} / \mathrm{L})$ & Total & $23.3 \pm 0.89$ & $1.5 \pm 0.07$ & $* * *$ \\
\hline \multirow[t]{3}{*}{$\mathrm{Cu}(\mu \mathrm{mol} / \mathrm{L})$} & Male & $16.0 \pm 1.04$ & $19.3 \pm 2.1$ & NS \\
\hline & Female & $18.1 \pm 1.2$ & $25.4 \pm 3.7$ & $*$ \\
\hline & Total & $16.8 \pm 0.8$ & $20.6 \pm 1.9$ & $* * *$ \\
\hline $\mathrm{Se}(\mu \mathrm{mol} / \mathrm{L})$ & Male & $7.9 \pm 0.34$ & $5.8 \pm 0.33$ & $* * *$ \\
\hline
\end{tabular}

*** Highly Significant difference $(p<0.001)$; * Significant difference $(p<0.05)$; NS: No Significant difference $(p>0.05)$.

\section{Diagnostic characteristics of parameters}

A measured parameter can only be useful if it is successfully put in a frame work that enables its use as either a "risk factor", to indicate the probability level of developing acute myocardial infarction (AMI) or a "marker", to indicate the presence and severity of AMI in inpatients.

To assess the effectiveness of a parameter as a diagnostic tool, researchers have developed the concepts of sensitivity, specificity and efficiency of tests (Apple et al., 1999).

Sensitivity of a test defines its capability to diagnose a patient and is given by, (Dardir et al., 1998):

$\mathbf{S}_{\mathbf{n}}=\left\{\mathbf{N}_{\mathrm{TP}} /\left(\mathbf{N}_{\mathrm{TP}}+\mathbf{N}_{\mathrm{TN}}\right)\right\} \times \mathbf{1 0 0}$
Where: $\mathrm{N}_{T P}$ is the number of successfully diagnosed patients and $\mathrm{N}_{\mathrm{TN}}$ is the number of successfully identified healthy persons in any sample.

The specificity is a measure of the capability of the test to isolate healthy persons, it is defined as:

$S_{p}=\left\{N_{T N} /\left(N_{T N}+N_{F P}\right)\right\} \times 100$.

Where: $\mathrm{N}_{\mathrm{FP}}$ is the number of healthy persons with positive test in the sample. Finally, the efficiency of any test is defined as:

$$
\left.E_{\mathrm{f}}=\left\{\mathrm{N}_{\mathrm{TP}}+\mathrm{N}_{\mathrm{TN}}\right) \mathrm{N}_{\mathrm{S}}\right\} \times 100 .
$$

Where: $\mathrm{N}_{\mathrm{S}}$ is the total sample size.

Successful implementation of the above measures to any marker requires an accurate estimation of the "cutoff 
value" or "reference interval" of the marker (Pezzilli et al., 2000). It is defined as "the usual value of a healthy population". Cutoff values can either be identified as the $95^{\text {th }}$ or $99^{\text {th }}$ percentiles of the control group values depending on the accuracy of the test. It could also be chosen to optimize the sensitivity and specificity according to the receiver operator characteristics (ROC) method (Bishop et al., 2010).

\section{The electrolyte group}

Table 3 presents the identified characteristics of the electrolyte group as related to the disease involved in this study. Among the electrolytes, $\mathrm{Na}^{+}$and $\mathrm{K}^{+}$showed the best characteristics with $\mathrm{S}_{\mathrm{n}}=100 \%, \mathrm{~S}_{\mathrm{P}}=85 \%$ and $\mathrm{E}_{\mathrm{f}}$ $=96 \%$ at the $95^{\text {th }}$ percentile. The results indicate that
$\mathrm{Na}^{+}$and $\mathrm{K}^{+}$are suitable to be considered as markers whereas $\mathrm{Cl}^{-}$showed a low value of sensitivity, indicating its weakness as a marker for AMI.

\section{The inorganic elements group}

Table 4 shows the sensitivity, specificity and efficiency of the inorganic elements involved in this study. Among these trace element, $\mathrm{Zn}^{2+}$ showed the best characteristics with $\mathrm{S}_{\mathrm{n}}$ $=100 \%, \mathrm{~S}_{\mathrm{P}}=100 \%$ and $\mathrm{E}_{\mathrm{f}}=100 \%$ at the $95^{\text {th }}$ percentile followed by Se with $\mathrm{S}_{\mathrm{n}}=70 \%, \mathrm{~S}_{\mathrm{P}}=100 \%$ and $\mathrm{E}_{\mathrm{f}}=$ $79 \%$.According to this observation, we could predict that $\mathrm{Zn}$ and Se could be considered as one of the important diagnostic tool for AMI, acting as antioxidants by scavenging the free radical that cause the atherosclerosis and consequently acute myocardial infarction.

Table 3. Clinical sensitivity, specificity and efficiency for electrolytes related to AMI patients.

\begin{tabular}{|c|c|c|c|c|}
\hline & \multicolumn{3}{|c|}{ Criterion } \\
\hline & Parameter & \multirow{2}{*}{$\begin{array}{l}99 \% \\
100\end{array}$} & \multirow{2}{*}{$\begin{array}{l}95 \% \\
106\end{array}$} & \multirow{2}{*}{\begin{tabular}{|l|} 
Mean \\
135.8
\end{tabular}} \\
\hline \multirow[t]{5}{*}{$\mathrm{Na}^{+}$} & Cutoff & & & \\
\hline & $\mathrm{S}_{\mathrm{n}}$ & 100 & 100 & \\
\hline & $S_{P}$ & 85 & 85 & \\
\hline & $\mathrm{E}_{\mathrm{ff}}$ & 96 & 96 & 94 \\
\hline & Cutoff & 2.0 & 2.3 & 4.04 \\
\hline \multirow[t]{3}{*}{$\mathbf{K}^{+}$} & $\mathrm{S}_{\mathrm{n}}$ & 100 & 100 & \multirow{2}{*}{$\begin{array}{l}100 \\
44\end{array}$} \\
\hline & $\mathrm{S}_{\mathrm{P}}$ & 85 & 85 & \\
\hline & $\mathrm{E}_{\mathrm{ff}}$ & 96 & 96 & \multirow{2}{*}{$\begin{array}{l}85 \\
100.38\end{array}$} \\
\hline \multirow[t]{4}{*}{$\mathrm{Cl}^{+}$} & Cutoff & 71.4 & 76 & \\
\hline & $\mathrm{S}_{\mathrm{n}}$ & 30 & 34 & 67 \\
\hline & $\mathrm{S}_{\mathrm{P}}$ & 100 & 91 & 29 \\
\hline & $E_{f f}$ & 47 & 49 & 59 \\
\hline
\end{tabular}

Table 4. Clinical sensitivity, specificity and efficiency for inorganic elements related to AMI patients.

\begin{tabular}{|c|c|c|c|c|}
\hline \multirow{2}{*}{\multicolumn{2}{|c|}{ Parameter }} & \multicolumn{3}{|c|}{ Criterion } \\
\hline & & \multirow{2}{*}{$\begin{array}{l}99 \% \\
1.29\end{array}$} & \multirow{2}{*}{$\begin{array}{l}95 \% \\
1.21\end{array}$} & \multirow{2}{*}{\begin{tabular}{|l} 
Mean \\
$\mathbf{0 . 8 5}$
\end{tabular}} \\
\hline Mg & Cutoff & & & \\
\hline & $S_{n}$ & 0 & 3 & 69 \\
\hline & $S_{P}$ & 94 & 94 & 67 \\
\hline & $\mathrm{E}_{\mathrm{ff}}$ & 25 & 28 & 69 \\
\hline \multirow[t]{4}{*}{$\mathbf{C a}$} & Cutoff & 2.02 & 2.06 & 2.48 \\
\hline & $S_{n}$ & 21 & 29 & 85 \\
\hline & $\mathrm{S}_{\mathrm{P}}$ & 98 & 97 & 50 \\
\hline & $\mathrm{E}_{\mathrm{ff}}$ & 64 & 65 & 66 \\
\hline \multirow[t]{4}{*}{ Zn } & Cutoff & 11.2 & 12 & 23.29 \\
\hline & $S_{n}$ & 100 & 100 & 100 \\
\hline & $\mathrm{S}_{\mathrm{P}}$ & 100 & 100 & 67 \\
\hline & $\mathrm{E}_{\mathrm{ff}}$ & 100 & 100 & 90 \\
\hline \multirow[t]{4}{*}{ Se } & Cutoff & 6.4 & 6.5 & 7.84 \\
\hline & $S_{n}$ & 70 & 70 & 95 \\
\hline & $S_{P}$ & 100 & 100 & 44 \\
\hline & $\mathrm{E}_{\mathrm{ff}}$ & 79 & 79 & 79 \\
\hline
\end{tabular}




\section{The effectiveness of groups of parameters as diagnostic tools}

In the proceeding sections, the characteristics of the individual parameters were analyzed and discussed. The differences between patients and healthy subjects were outlined and the use of the different parameters as risk factors or illness markers was discussed as well. To increase the power of diagnosis, the trend now is to use two or more parameters in a group form to diagnose or indicate illness (Pezzilli et al., 2000). This task can be achieved through performing discriminant analysis which uses present patients and healthy subjects' data to extract discriminant functions that can be used to assign subjects to any of the two groups based on the outcome of such functions after feeding them with the required test values.

The analysis starts from the biochemical groups with the addition of age and sex to each of the groups. A backwards stepwise technique is used to eliminate ineffective parameters whose $p>0.05$. The outcome of the analysis is a function of the form:

$$
f=a_{o}+\Sigma a_{i} x_{i}, i=1, n
$$

Where, the a's are constants, the x's are the studied parameters and $\mathrm{f}$ is the discriminating variable. Based on the value of $f$, $(f<0$ or $f>0)$, the examined subject is assigned to group one or two, (healthy or sick, low risk or high risk). $\mathrm{f}=0$ marks the equal probability line for the subject to belong to any of the groups. The final outcome is the discrimination efficiency $\left(\eta_{d}\right)$ which marks the correctness extent of the function in assigning subjects.

\section{The electrolytes group discrimination function}

This group consists of $\mathrm{Na}^{+}, \mathrm{K}^{+}$and $\mathrm{Cl}^{-}$in addition to age and sex. The final model is given as:

$$
f_{e l}=1367.839+11.716 \times s e x-16.999 \times N a-48.534 \times K
$$

Where $\mathrm{f}_{\mathrm{el}}$ is the discrimination function for electrolytes. Age and $\mathrm{Cl}$ were removed by the analysis and the discrimination efficiency of the function is $100 \%$.

\section{Conclusion}

The imbalance of serum electrolytes and inorganic elements in acute myocardial infarction reflects the importance of measuring these parameters as a diagnostic tool for medical management of the burden of the disease. Serum electrolytes and inorganic elements might be good predictors for the identification of risk of acute myocardial infarction. Serum electrolytes like $\mathrm{Na}^{+}$, $\mathrm{K}^{+}$and inorganic elements like $\mathrm{Zn}^{2+}$ and Se could be considered as illness indicators or markers of early acute myocardial infarction.Therefore, monitoring of serum electrolytes and inorganic elements in acute myocardial infarction is necessary for the effective management of the disease. The grouping of parameters gave tools for using as a risk factor and/or diagnostic markers with efficiency over individual parameters.

\section{Conflict of interest statement}

Authors declare that they have no conflict of interest.

\section{References}

Abhinav, G., John, A., Kensey, G., Lakshmi, V., Philip, G., Greet, V., Mikhail, K., 2012. Serum potassium levels and mortality in acute myocardial infarction. J. Amer. Med. Assoc. 307(2), 157-164.

Abid, F., Al-Dori K., Khalaf, H., Al-Kubisi, R., Salomi, A., 2002. Measurement of some essential trace elements in blood serum of cardiovascular patients compared with normotensive control by atomic absorption spectroscopy. Nat. J. Chem. 6, 283-304.

Ahmad, M.I., Sharma, N., 2012. Biomarkers in acute myocardial infarction. J. Clin. Exp. Cardiol. 3, 222.

Al-Sabaawy, O. M., 2012. The relationship between serum lipid profile and selected trace elements for adult men in Mosul city. Oman Med. J. 27(4), 300303.

Altura, B.M., Altura, B.T., 1995. Cell Mol. Biol. Res., 41: 347. Cited by Nat. J. Chem., 6, (2012).

Apple, F.S., Anderson F.P., Collinson P., 1999.Clinical evaluation of the first medical whole blood, pointof-care testing device for detection of myocardial infarction. Clin. Chem. 46(10), 1604-1609.

Bender, D.A., Botham, K.M., Kennelly, P.J., Rodwell, V.W., Anthony, W.P., 2015. Harpers Illustrated Biochemistry. $30^{\text {th }}$ Edn. McGraw-Hill Medical pp.781-783.

Bishop, M., Duben, J., and Fody, E., 2010.Clinical Chemistry: Techniques, Principles and Correlations. $6^{\text {th }}$ Edn. Lipincott Williams and Wilkins. pp.541555.

Burtis, C.A., Ashwood, E.R., David, E. B., 2008. Tietz Fundamentals of Clinical Chemistry. $6^{\text {th }}$ Edn. W B Saunders Company, USA. pp.614-630. 
Burtis, C.A., Ashwood, E.R., David, E. B., 2013. Tietz Textbook of Clinical Chemistry and Molecular Diagnostics, $5^{\text {th }}$ Edn. pp.1240-1255.

Candeias, L.P., Patel, K.B., Stratford M.R., Wardman P., 1993. FBES Lett., 333, 151 Cited by Alta'ee A.H. (2012), M.Sc. Thesis, College of Science, University of Babylon, Iraq.

D'Haese, P.C., Lamberts, L.V., Vanheule, A.O., Debroe, M.E., 1992.Direct determination of zinc in serum by Zeeman atomic absorption spectrometry with a graphite furnace. Clin. Chem. 38(12), 2439-2443.

Dardir, M.D., Abd, E.S., Moktar, S., 1998.Value of determination of different laboratory markers of acute myocardial infarction in a time-related frame. Egypt Heart J. 50, 1-18.

Gallerani, M., Manfredini, R., Vanara F., 1994. Variation in serum ion levels in acute myocardial infarction: Possible insights for diagnosis and therapy. Curr. Therap. Res. 3, 343-347.

George, L., Evangelos, L., Fotios, B., Moses, E., 2014. Diabetes mellitus and electrolyte disorders. World J Clin. Cases. 162(10), 488-496.

Jialal, Devaraj.,1998. Clin. Chem., 42: 498. Cited by
Nat. J. Chem., 6, (2012).

John, E., Macdonald., Allan D., Struthers., 2004. What is the optimal serum potassium level in cardiovascular patients. JAM Coll. Cardiol. 43, 155161.

Kaplan, L., Pesce, A., 2010. Clinical Chemistry- Theory, Analysis, Correlation. $5^{\text {th }}$ Edn. Mosby/Elsevier. pp.1021-25.

Kim, A., 1999. Selenium and cardiovascular pathology. Bur. Heart J. 20(22), 1676-1680.

Pezzilli, R., D’Eril, G., Morselli, A., 2000. Serum amyloid $\mathrm{A}$, procalcitonin and c-reactive protein in early assessment of severity of acuter pancreatitis. Digest. Dis. Sci. 6, 1072-1078.

Shanmugasundaram, K.R., 1999. Am. J. Clin. Nutr. 70(30): 625S. Cited in Nat. J. Chem., 6, (2012).

Snedecor, G., Cochran., G. 1986. Statistical methods. Lowa State University Press, Ames, $90.7^{\text {th }}$ ed. Cited 2016.

Snell, F.D., 1981. Photometric and Flurometric Methods of Analysis, Non Metals. John Wiley and Sons, New York. pp.482-517.

\section{How to cite this article:}

Ismail, M. K., Mustafa, L. A., Karanghadan, A. S., 2017. Study of effectiveness of serum electrolytes and inorganic elements as biomarkers in acute myocardial infarction patients. Int. J. Curr. Res. Biosci. Plant Biol. 4(3), 57-63. doi: https://doi.org/10.20546/ijcrbp.2017.403.006 